\title{
Urinary tract infections at first antenatal check-up: a single centre prospective study
}

\author{
Saubhagya Kumar Jena ${ }^{1}$, Rajashree Panigrahy ${ }^{2}$, Lipsa Mishra ${ }^{1}$, Suren Kumar Das ${ }^{3}$, \\ Soumya Samal ${ }^{4}$
}

\begin{abstract}
${ }^{1}$ Department of Obstetrics and Gynaecology, AIIMS Bhubaneswar, Odisha, India
${ }^{2}$ Department of Microbiology, ${ }^{3}$ Department of Urology, ${ }^{4}$ Department of Anaesthesiology, IMS and SUM Hospital, Bhubaneswar, Odisha, India
\end{abstract}

Received: 14 July 2016

Accepted: 06 August 2016

\section{*Correspondence:}

Dr. Saubhagya Kumar Jena,

E-mail: drsaubhagya@gmail.com

Copyright: (c) the author(s), publisher and licensee Medip Academy. This is an open-access article distributed under the terms of the Creative Commons Attribution Non-Commercial License, which permits unrestricted non-commercial use, distribution, and reproduction in any medium, provided the original work is properly cited.

\begin{abstract}
Background: Pregnant women with asymptomatic bacteriuria (ASB) are more likely to develop acute pyelonephritis, postpartum UTI, hypertensive disease, anemia, prematurity, low birth weight babies and prenatal death if untreated. Methods: Total 780 pregnant women attending for first antenatal check-up in a medical college were enrolled for the study. Those with any symptoms of UTI, like burning micturition, frequency, urgency, dysuria or fever were excluded from the study. All were subjected to undergo urine culture and sensitivity to the commonly used antibiotics in that area, irrespective of period of gestation, age and parity. Prevalence of ASB, most common infecting organism and antibiotic sensitivity pattern were analyzed.

Results: The prevalence of ASB in $<25$ years age group was significantly higher than in $>25$ years age group $(26.06 \%$ versus $18.80 \% ; \mathrm{p}=0.020)$. Out of the 780 culture samples, 52 had more than 3 type colonies indicating contamination and 22 had budding yeast colonies, thus excluded from the study. No growth was found in 551 samples (78.05\%). The prevalence of ASB was $21.95 \%$. The most common organism isolated was ESBL-ve E coli (32.25\%), followed by ESBL + ve E coli (21.29\%) and Enterococcus (15.48\%) respectively. E coli were mostly sensitive to nitrofurantoin, amikacin and cotrimoxazole whereas enteroccocus was sensitive to vancomycin.

Conclusions: ASB is more common during pregnancy even in first antenatal check-up. We suggest routine urine culture and sensitivity during first antenatal check-up to detect ASB and treat with proper antibiotic to prevent the complications and development of resistance.
\end{abstract}

Keywords: Antenatal Check-up, Asymptomatic Bacteriuria, Pregnancy, UTI

\section{INTRODUCTION}

Urinary tract infections (UTI) are one of the most common medical complications of pregnancy. ${ }^{1}$ UTI may be symptomatic or asymptomatic. The symptomatic forms may present as urethritis, cystitis, acute pyelonephritis and pyelonephritis with bacteremia or sepsis. $^{2}$ The asymptomatic form known as asymptomatic bacteriuria (ASB) is defined as the presence of significant bacteriuria i.e., $10^{5}$ bacteria per milliliter $(\mathrm{ml})$, without the symptoms of an acute urinary tract infection. ${ }^{3}$
Pregnant women with ASB are more likely to develop acute pyelonephritis, postpartum UTI, hypertensive disease, anemia, prematurity, low birth weight babies and prenatal death if untreated. ${ }^{3,4}$ A 2007 Cochrane systematic review and meta-analysis of 14 randomized trials involving 2302 pregnant women compared antibiotic treatment with placebo or no treatment and found significant reductions in the incidence of pyelonephritis and low-birth weight babies in the antibiotic treated group. ${ }^{5}$ Screening for and treatment of ASB in pregnancy by urine culture sensitivity testing has become a routine in obstetrics and most antenatal 
guidelines recommend the same. ${ }^{4}$ None of the currently available screening tests have a high enough sensitivity and negative predictive value for ASB in pregnant women to replace the urine culture. Testing in each trimester is advocated by some but future research is needed to clarify the optimal timing and periodicity of screening in pregnant women. ${ }^{6,7}$ The present study was intended to study the prevalence of asymptomatic bacteriuria in pregnant women in their first antenatal check-up and to detect the antibiotic sensitivity pattern in the same group.

\section{METHODS}

This is a single center observational study where 780 pregnant women attending for first antenatal checkup in a medical college were enrolled, during the period from May 2011 till March 2012. Those with any symptoms of UTI, like burning micturition, frequency, urgency, dysuria or fever were excluded from the study. Also women with disorders predisposing to UTI, like diabetes, urinary calculi, congenital malformations of urinary tract and immunological disorders were excluded. Informed consent was taken and all were subjected to undergo urine culture and sensitivity to commonly used antibiotics in that area, after properly explaining regarding the method of obtaining midstream clean catch urine samples, irrespective of period of gestation, age and parity. A clean catch mid-stream urine was collected in clean wide mouthed container. Then after labeling it properly, the sample was transferred to the laboratory.

In laboratory the routine and microscopic test was done and then the sample was processed for culture and sensitivity testing. For culture we used the CLED (cystine lactose electrolyte deficient) agar plate with a $4 \mathrm{~mm}$ diameter loop of 26-gauge loop which inoculate $0.01 \mathrm{ml}$ of urine on the plate. The sensitivity test was done on muller hinton agar plate using Kirby bauer method. The organism identification was done on the basis of standard protocol method described in the text book. ${ }^{8}$

The study and data collection was carried out with the approval from the Institutional Ethical Committee. Results were analyzed and prevalence of asymptomatic bacteriuria, most common infecting organism and antibiotic sensitivity found and compared with other studies. Data entry and analysis was performed using SPSS software. Difference between proportions was calculated by the ' $Z$ ' value. P-value less than 0.05 were considered as statistically significant.

\section{RESULTS}

The age range in the study was from 18 to 38 years. The median and mean ages were 25 years and $25.25 \pm 4.12$ years respectively. Majority of the study population $(90 \%)$ were below 30 years of age (Table 1$)$.
Table 1: Age distribution of total and culture positive cases.

\begin{tabular}{|c|c|c|}
\hline Age group & $\begin{array}{l}\text { Number of } \\
\text { cases }(\%) \\
N=780\end{array}$ & $\begin{array}{l}\text { Culture positive } \\
\text { number }(\%) \\
N=155\end{array}$ \\
\hline 18 to 20 years & $80(10.25 \%)$ & $13(8.38 \%)$ \\
\hline$>20$ to 25 years & $352(45.12 \%)$ & $67(43.22 \%)$ \\
\hline$>25$ to 30 years & $259(33.20 \%)$ & $56(36.12 \%)$ \\
\hline$>30$ to 35 years & $76(9.74 \%)$ & $17(10.96 \%)$ \\
\hline$>35$ to 38 years & $13(1.66 \%)$ & $02(1.29 \%)$ \\
\hline
\end{tabular}

Table 2: Microbiology of UTI during pregnancy $(\mathrm{N}=\mathbf{7 8 0})$.

\begin{tabular}{|l|l|}
\hline Organism & Number (\%) \\
\hline No growth & $551(70.64 \%)$ \\
\hline$\geq 3$ types of colonies & $52(6.66 \%)$ \\
\hline Budding yeast cells (BYC) & $22(2.82 \%)$ \\
\hline Culture positive & $155(21.95 \%)$ \\
\hline Acinetobacter ESBL -ve & 02 \\
\hline Acinetobacter ESBL +ve & 01 \\
\hline Atypical E Coli ESBL -ve & 02 \\
\hline Atypical E Coli ESBL +ve & 01 \\
\hline Citrobacter ESBL -ve & 01 \\
\hline Citrobacter ESBL +ve & 01 \\
\hline $\begin{array}{l}\text { Coagulase negative staphyloccus } \\
\text { (CONS) }\end{array}$ & 01 \\
\hline E. Coli ESBL -ve & 50 \\
\hline E. Coli ESBL +ve & 33 \\
\hline Enterococcus & 24 \\
\hline Klebsilla species ESBL -ve & 13 \\
\hline Klebsilla species ESBL +ve & 03 \\
\hline Proteus species ESBL -ve & 03 \\
\hline Proteus species ESBL +ve & 01 \\
\hline Pseudomonas species ESBL -ve & 06 \\
\hline MSSA & 03 \\
\hline MRSA & 10 \\
\hline
\end{tabular}

The prevalence of ASB in $<25$ years age group is significantly higher than in $>25$ years age group $(26.06 \%$ versus $18.80 \% ; \mathrm{p}=0.020)$. Out of the 780 culture samples, 52 had more than 3 type colonies indicating contamination and 22 had budding yeast colonies, thus excluded from the study. No growth was found in 551 samples $(78.05 \%)$. The prevalence of ASB was $21.95 \%$ (Table 2). The most common organism isolated was E. Coli $(53.54 \%)$ out of that extended spectrum beta lactamase (ESBL) -ve E. Coli (32.25\%), followed by ESBL +ve E coli (21.29\%) and next common was Enterococcus (15.48\%). Other organisms constituting around $31 \%$, included Klebsiella (10.3\%), methicillin resistant staphylococcus aureus (MRSA) (6.45\%), pseudomonas, proteus, coagulase negative staph aureus and citrobacter respectively (Table 3 ). 
Table 3: Common organisms isolated in ASB.

\begin{tabular}{|ll|}
\hline Organism & Number $(\%) \mathbf{N}=155$ \\
\hline E. Coli ESBL -ve & $50(32.25 \%)$ \\
\hline E. Coli ESBL +ve & $33(21.29 \%)$ \\
\hline Enterococcus & $24(15.48 \%)$ \\
\hline Klebsilla species & $16(10.32 \%)$ \\
\hline MRSA & $10(6.45 \%)$ \\
\hline
\end{tabular}

Table 4: Comparison of ASB prevalence in pregnancy in various studies.

\begin{tabular}{|ll|}
\hline Authors & $\begin{array}{l}\text { Prevalence of } \\
\text { asymptomatic bacteriuria }\end{array}$ \\
\hline Kass, in MacLean & $6 \%$ \\
\hline Lawson & $4.6 \%$ \\
\hline $\begin{array}{l}\text { Campbell-Brown in } \\
\text { MacLean }\end{array}$ & $2.6 \%$ \\
\hline Chng & $12 \%$ \\
\hline Robertson & $8.3 \%$ \\
\hline Hagay & $7.6 \%$ \\
\hline Sheiner & $2.5 \%$ \\
\hline Mignini & $15 \%$ \\
\hline Sujatha et al & $7.3 \%$ \\
\hline Chandel et al & $7.3 \%$ \\
\hline Neupane MS et al & $26 \%$ \\
\hline Imade PE et al & $45.3 \%$ \\
\hline Our Study & $21.95 \%$ \\
\hline
\end{tabular}

Table 5: Antibiotic sensitivity of commonly isolated organisms.

\begin{tabular}{|ll|}
\hline Organism & Antibiotic sensitivity \\
\hline \multirow{2}{*}{ E. Coli ESBL -ve } & $\begin{array}{l}\text { Nitrofurantoin } \\
\text { Amikacin } \\
\text { Cotrimaxazole }\end{array}$ \\
\hline E. Coli ESBL +ve & $\begin{array}{l}\text { Nitrofurantoin } \\
\text { Amikacin } \\
\text { Piperacilin+Tazobactem } \\
\text { Cotrimaxazole }\end{array}$ \\
\hline Enterococcus & Vancomycin \\
\hline Klebsilla Species & $\begin{array}{l}\text { Amikacin } \\
\text { Piperacilin+Tazobactem }\end{array}$ \\
\hline \multirow{2}{*}{ MRSA } & Linozolid \\
& Vancomycin \\
& Amikacin \\
\hline
\end{tabular}

E. coli were mostly sensitive to amikacin and nitrofurantoin and cotrimoxazole whereas enteroccocus was sensitive to vancomycin (Table 5).

\section{DISCUSSION}

In this study $79.2 \%$ culture positive patients were in age group of 21-30 years followed by women $>30$ years i.e. $12.33 \%$ which is similar to studies by Sujatha et al and Alghalibi et al. ${ }^{8,9}$ This could be due to the fact that many women in this age group are likely to have had many children before the present pregnancy and multiparty has been reported as a risk factor for asymptomatic bacteriuria in pregnancy. ${ }^{10}$ When divided in two groups the prevalence of ASB in women less than equal to 25 years is significantly higher than those more than 25 years $(\mathrm{p}=0.02)$. This may be probably due to higher incidence of honeymoon cystitis in younger age groups. Other studies have reported higher prevalence in elderly age groups and that advanced maternal age is an independent risk factor for ASB in pregnancy. ${ }^{11,12}$

The prevalence of ASB as a whole is $21.95 \%$, which is similar to another study in Nigeria (Table 4). It is much higher than studies done by Sujatha et al, Chandel et al were it was $7.3 \%$ and by Celen et al where it is $8.5 \% .^{8,13-}$

${ }^{15}$ It was lower than other studies which have reported prevalence of ASB as high as $26 \%$ and $45.3 \%$ respectively (Table 4). ${ }^{16,17}$

This variation may be explained by differences in the environments, social habits, socio-economic statuses, personal hygiene and education of the patients who were studied.

Most common organism isolated was ESBL -ve E. coli $(32.25 \%)$ followed by ESBL +ve E. coli $(21.29 \%)$ and Enteroccocus $(15.48 \%)$ respectively. E. coli was the most common organism isolated in various other studies whereas enterococcus is among the rarely isolated organism. $^{11,18}$ E. coli infection occurs mostly due to urinary stasis, poor genital hygiene practices and fecal contamination. ${ }^{17}$

E. coli both ESBL -ve and +ve were mostly sensitive to nitrofurantoin, amikacin, piperacillin-tazobactam and cotrimoxazole whereas enteroccocus was sensitive to vancomycin similar to other studies. ${ }^{18,19}$ In our study though ESBL -ve E coli was most commonly isolated, they were sensitive to the common antibiotics. To prevent development of resistance, sensitivity testing is mandatory.

\section{CONCLUSION}

ASB is more common during pregnancy even in first antenatal check-up. The most common organisms isolated were $\mathrm{E}$ coli (ESBL -ve and +ve) and Enterococcus. Although E coli were mostly sensitive nitrofurantoin, enteroccocus was sensitive to vancomycin. We suggest routine urine culture and sensitivity during first antenatal check-up to detect ASB and treat with proper antibiotic to prevent the complications and development of resistance.

Funding: No funding sources

Conflict of interest: None declared

Ethical approval: The study was approved by the Institutional Ethics Committee 


\section{REFERENCES}

1. Mittal P, Wing DA. Urinary tract infections in pregnancy. Clin Perinatol. 2005;32(3):749-64.

2. DiPiro J, Gary Yee RT, Matzke G, Wells B, Posey LM. Pharmacotherapy: a pathophysiologic approach. McGraw-Hill Medical; 2011.

3. Connolly A, Thorp JM. Urinary tract infections in pregnancy. Urol Clin North Am. 1999;26(4):779-87.

4. Jayalakshmi J, Jayaram VS. Evaluation of various screening tests to detect asymptomatic bacteriuria in pregnant women. Indian $\mathbf{J}$ Pathol Microbiol. 2008;51(3):379-81.

5. Smaill F, Vazquez JC. Antibiotics for asymptomatic bacteriuria in pregnancy. Cochrane Database Syst Rev. 2007;CD000490.

6. McIsaac W, Carroll JC, Biringer A, Bernstein P, Lyons E, Low DE, et al. Screening for asymptomatic bacteriuria in pregnancy. J Obstet Gynaecol Can. 2005;27(1):20-4.

7. Lin K, Fajardo K. Screening for asymptomatic bacteriuria in adults: evidence for the U.S. preventive services task force reaffirmation recommendation statement. Ann Intern Med. 2008;149:W20-W24.

8. Mackie and McCartney Practical Medical Microbiology, $14^{\text {th }}$ edition. Publisher Elsevier; 1996:131-150.

9. Sujatha R, Nawani M. Prevalence of asymptomatic bacteriuria and its antibacterial susceptibility pattern among pregnant women attending the antenatal clinic at Kanpur, India. Journal of Clinical and Diagnostic Research. JCDR. 2014;8(4):DC01-3.

10. Alghalibi SM, Al-Jaufy A, Al-Moayad E. Bacterial urinary tract infection among pregnant women in Sana'a City-Yemen. Arab Gulf Journal of Scientific Research. 2007;25:23-31.
11. Fatima N, Ishrat S. Frequency and risk factors of asymptomatic bacteriuria during pregnancy. J Coll Physicians Surg Pak. 2006;16:273-5.

12. Turpin CA, Minkah B, Danso KA, Frimpong EH. Asymptomatic bacteriuria in pregnant women attending antenatal clinic at komfo anokye teaching hospital, Kumasi. Ghana Medical Journal. 2007;41(1):26-9.

13. Akinloye O, Ogbolu DO, Akinloye OM, Alli OA. Asymptomatic bacteriuria of pregnancy in Ibadan, Nigeria: a re-assessment. $\mathrm{Br} \mathrm{J}$ Biomed Sci. 2006;63:109-12.

14. Olusanya O, Ogunledum A, Fakoya TA. Asymptomatic significant bacteriuria among pregnant and non-pregnant women in Sagamu, Nigeria. WAJM. 1993;12(1):27-33.

15. Chandel R, Kanga A, Thakur K, Mokta KK, Sood A, Chauhan S. Prevalence of pregnancy associated asymptomatic bacteriuria: a study done in a tertiary care hospital. J Obstet Gynaecol India. 2012;62(5):511-4.

16. Celen S, Oruc AS, Karayalcin R, Saygan S, Unlu S, Polat B, et al. Asymptomatic bacteriuria and antibacterial susceptibility patterns in an obstetric population. ISRN Obstet Gynaecol. 2011;2011:Article ID 721872.

17. Neupane MS, Dhakal KS, Neupane HC, Adhikari S, Aryal B. Asymptomatic bacteriuria among pregnant women attending the outpatient clinics of chitwan medical college teaching hospital in Chitwan, Nepal. IRJP. 2012;3(11):78-80.

18. Imade PE, Izekor PE, Eghafona NO, Enabulele OI, Ophori E. Asymptomatic bacteriuria among pregnant women. N Am J Med Sci. 2010;2(6):263-6.

19. Girishbabu RJ, Srikrishna R, Ramesh ST. Asymptomatic bacteriuria in pregnancy. Int $\mathrm{J}$ Biol Med Res. 2011;2(3):740-74.

Cite this article as: Jena SK, Panigrahy R, Mishra L, Das SK, Samal S. Urinary tract infections at first antenatal check-up: a single centre prospective study. Int J Reprod Contracept Obstet Gynecol 2016;5:3103-6. 